\title{
Minimum detection limit of an in-house nested-PCR assay for herpes simplex virus and varicella zoster virus
}

\author{
Diógenes Rodrigues ${ }^{[1]}$, Fernanda de-Paris ${ }^{[2]}$ and Rodrigo Minuto Paiva ${ }^{[2]}$
}

[1]. Programa de Residência Integrada Multiprofissional em Saúde, Hospital de Clínicas de Porto Alegre, Universidade Federal do Rio Grande do Sul, Porto Alegre, RS. [2]. Serviço de Patologia Clínica, Unidade de Pesquisa Biomédica, Hospital de Clínicas de Porto Alegre, Universidade Federal do Rio Grande do Sul, Porto Alegre, RS.

Introduction: Herpes simplex virus (HSV) and varicella zoster virus (VZV) are responsible for a variety of human diseases, including central nervous system diseases. The use of polymerase chain reaction (PCR) techniques on cerebrospinal fluid samples has allowed the detection of viral DNA with high sensitivity and specificity. Methods: Serial dilutions of quantified commercial controls of each virus were subjected to an in-house nested-PCR technique. Results: The minimum detection limits for HSV and VZV were 5 and 10 copies/ $\mu \mathrm{L}$, respectively. Conclusions: The detection limit of nested-PCR for HSV and VZV in this study was similar to the limits found in previous studies.

Keywords: Herpes simplex virus. Varicella zoster virus. Polymerase chain reaction.

Herpes simplex virus type 1 and type 2 (HSV-1, HSV-2) and varicella zoster virus (VZV), which belong to the Herpesviridae family, are morphologically very similar, with large doublestranded linear deoxyribonucleic acid (DNA) genomes ${ }^{1}$. These viruses are associated with a variety of clinical symptoms, including central nervous system (CNS) diseases such as meningitis, severe encephalitis, skin and mucosal infections and keratoconjunctivitis ${ }^{2}$. In immunocompromised patients, the viruses may also trigger severe clinical conditions, including pneumonia and disseminated infection ${ }^{1,2}$.

The prevalence rates of HSV-1 and 2 vary widely between and within countries; however, it is well known that HSV is highly prevalent in the general population ${ }^{3}$. Both viruses are transmitted through contact with infected skin during viral reactivations. Most commonly, HSV-1, or oral herpes, causes sores around the mouth and lips (also called fever blisters or cold sores) and can infect the CNS. Although HSV-1 can cause genital herpes, most cases of genital herpes are caused by HSV2. Unlike HSV-1 infection, which usually establishes latency in the trigeminal ganglion, typically causing an encephalitic illness, HSV-2 usually establishes latency in the sacral sensory ganglia and typically causes a meningitic illness ${ }^{1,4}$. HSV-2 sometimes causes sores around the genitals or rectum. Although HSV-2 sores may occur in other locations, they are usually found below the waist ${ }^{3}$.

Primary VZV infection causes varicella or chicken pox, a frequent illness affecting health professionals and the general

Address to: Dr. Rodrigo Minuto Paiva. Unidade de Microbiologia e Biologia Molecular/HCPA/UFRGS. Rua Ramiro Barcelos 2350, 90035-903 Porto Alegre, RS, Brasil.

Phone: 5551 3359-8860; Fax 5551 3359-8310

e-mail: rpaiva@hcpa.ufrgs.br

Received 31 January 2012

Accepted 6 June 2012 population alike. Varicella is considered to be a highly infectious disease with high incidence among children. VZV can also reactivate from its latent state to cause herpes zoster or shingles, which is more common in the elderly. CNS complications can follow both primary infection and reactivation of VZV as meningitis and encephalitis. The more severe manifestations arise when VZV invades the spinal cord or cerebral arteries after viral reactivation, causing diseases such as myelitis and focal vasculopathies ${ }^{5,6}$.

Before the introduction of molecular techniques, laboratory diagnosis of viral infections of the CNS, such as meningitis caused by HSV or VZV, relied on virus isolation in cell culture, detection of specific antibody production in cerebrospinal fluid (CSF) or, for encephalitis caused by HSV, viral antigen detection in brain biopsy specimens. The clinical usefulness of viral culture of CSF for the detection of HSV and VZV is limited because of poor sensitivity ${ }^{7}$. Serological techniques have no role in the diagnosis of active HSV or VZV diseases such as genital infection or encephalitis ${ }^{1}$. Polymerase chain reaction (PCR) protocols (commercial or in-house assays) have emerged as a tool for the rapid and accurate diagnosis of CNS infections ${ }^{4}$. The sensitivity of PCR for the diagnosis of CNS disease is high for HSV encephalitis and enteroviral meningitis, increasing our understanding of the etiological roles of viruses in CNS disease ${ }^{8,9}$.

Many molecular biology laboratories use in-house PCR assays - techniques specifically developed by laboratories for the diagnosis of infectious diseases. However, the lack of standardization and the poor reproducibility of in-house techniques have been argued as limitations against their routine use as diagnostic methods. When developing in-house PCR assays, one of the parameters to be analyzed as part of standardization studies is the minimum detection limit.

In this context, the purpose of this study was to determine the detection threshold of a duplex nested-PCR technique for 
HSV and VZV that was standardized by the Molecular Biology Laboratory of the Hospital de Clínicas de Porto Alegre.

Serial dilutions of viral DNA of known concentrations $\left(1.3 \times 10^{4}\right.$ and $1.7 \times 10^{4}$ copies $\left./ \mu \mathrm{L}\right)$ were prepared from quantified HSV and VZV commercial controls (Advanced Biotechnologies $^{\circledR}$, Columbia, USA), respectively. Nine-fold dilutions of each virus $(1,000,500,250,100,75,50,10,5$ and $1 \mathrm{copy} / \mu \mathrm{L})$ were subjected to nested-PCR. Extraction and purification of viral nucleic acids were performed using a QIAamp Viral RNA Mini Kit (Qiagen ${ }^{\circledR}$, Valencia, USA) according to the manufacturer's instructions. The dilutions were then submitted to an in-house nested-PCR assay. This technique uses two stages of consecutive amplification, with the products of the first reactions (413bp for HSV and $272 \mathrm{bp}$ for VZV) serving as the targets for the second (280bp for HSV and 208bp for VZV). That is, in this assay, second amplification primers lie (are nested) within the first amplification primers. HSV and VZV external (HSV: 5' ATC CGA ACG CAG CCC CGC TG and 5' TCC GGS GGC AGC AGG GTG CT; VZV: 5' ACG GGT CTT GCC GGA GCT GGT and 5'AAT GCC GTG ACC ACC AAG TAT AAT) and internal primers (HSV: 5' GCG CCG TCA GCG AGG ATA AC and 5' AGC TGT ATA SGG CGA CGG TG; VZV: 5' ACC TTA AAA CTC ACT ACC AGT and 5' CTA ATC CAA GGC GGG TGC AT) amplify fragments of the D glycoprotein gene and gene 29 that are present in HSV and VZV genomes, respectively ${ }^{9}$. The first-stage PCR reaction contained $16 \mathrm{mM}\left(\mathrm{NH}_{4}\right)_{2} \mathrm{SO}_{4}, 67 \mathrm{mM}$ Tris- $\mathrm{HCl}\left(\mathrm{pH} 8.8,25^{\circ} \mathrm{C}\right)$, $1.5 \mathrm{mM} \mathrm{MgCl}, 0.01 \%$ (w/v) Tween-20 (Southern Cross Biotechnology Ltd., Cape Town, South Africa), $0.25 \mathrm{mM}$ of each dNTP, $0.2 \mu \mathrm{M}$ primers and 2.5U DNA Super-Therm polymerase (Southern Cross Biotechnology Ltd., Cape Town, South Africa). The final volume of the reaction mixture was $50 \mu \mathrm{L}$ and contained $20 \mu \mathrm{L}$ of DNA extracted from the commercial controls. Amplification was conducted in a Techne Thermocycler TC414 (Techne ${ }^{\circledR}$, New Jersey, USA). The reaction began with denaturation at $94^{\circ} \mathrm{C}$ for $1 \mathrm{~min}$ and $45 \mathrm{~s}$, followed by 33 cycles at $94^{\circ} \mathrm{C}$ for $30 \mathrm{~s}$, annealing at $60^{\circ} \mathrm{C}$ for $30 \mathrm{~s}$ and polymerization at $72^{\circ} \mathrm{C}$ for $30 \mathrm{~s}$. In the second amplification reaction, the reaction mixture was identical to the first; however, half of the individual volumes of the reagents were used, and $2 \mu \mathrm{L}$ of the amplicon obtained in the first reaction was added. Additionally, the internal instead of the external primers were used. The reaction began with denaturation at $94^{\circ} \mathrm{C}$ for $45 \mathrm{~s}$, followed by 33 cycles at $94^{\circ} \mathrm{C}$ for $20 \mathrm{~s}$, annealing at $60^{\circ} \mathrm{C}$ for $30 \mathrm{~s}$ and polymerization at $72^{\circ} \mathrm{C}$. The final products of these reactions were electrophoresed on $2 \%$ agarose gels stained with $0.5 \mu \mathrm{g} / \mathrm{mL}$ ethidium bromide. All testing was performed with 100- to 1,000-bp molecular weight markers (Invitrogen ${ }^{\circledR}$, Carlsbad, USA). As a negative control, a reaction containing $20 \mu \mathrm{L}$ of sterile water was used instead of the commercial control dilutions. The results were qualitatively expressed as positive (amplified DNA product) or negative.

For the statistical analysis, WinPepi ${ }^{\circledR}$ (version 10.5) was used to calculate the number of PCR assay repetitions. For a sensitivity of $90 \%$, with a $10 \%$ error margin (assuming a significance level of $95 \%$ ), it was necessary to perform the PCR assay at least 33 times for each dilution. The lower limit of detection was defined as the lowest concentration of viral DNA yielding $100 \%$ positivity in all repetitions. For testing categorical variables with PCR results, Fisher's exact test was used with a $95 \%$ confidence interval ${ }^{10}$.

First, all nine dilutions ( 1 to 1,000 copies $/ \mu \mathrm{L}$ ) were tested for HSV to determine the lowest range of dilution for further testing. Because amplification of the target product was observed with both smaller and larger dilutions, it was established that the assay's minimum detection limit would most likely be between 1 and 10 copies $/ \mu \mathrm{L}$. Therefore, at least 33 repetitions of the nested PCR assay were performed for each virus within a range of higher dilutions, with $20 \mu \mathrm{L}$ of extracted DNA.

The lower limits of detection were determined to be 5 copies $/ \mu \mathrm{L}$ for HSV and 10 copies $/ \mu \mathrm{L}$ for VZV (Table 1). To verify whether the PCR protocol was specific for HSV and

TABLE 1 - Percentages of positivity for herpes simplex virus and varicella zoster virus in nested-PCR.

\begin{tabular}{|c|c|c|c|c|c|c|}
\hline \multirow[b]{3}{*}{ Viral DNA dilutions } & \multicolumn{3}{|c|}{ HSV } & \multicolumn{3}{|c|}{ VZV } \\
\hline & \multirow[b]{2}{*}{ PCR repetitions } & \multicolumn{2}{|c|}{ positive amplifications } & \multirow[b]{2}{*}{ PCR repetitions } & \multicolumn{2}{|c|}{ positive amplifications } \\
\hline & & $\mathrm{n}$ & $\%$ & & $\mathrm{n}$ & $\%$ \\
\hline 1 сору $/ \mu \mathrm{L}$ & 33 & 26 & 78.7 & 33 & 11 & 33.3 \\
\hline 5 copies $/ \mu \mathrm{L}$ & 33 & 33 & 100.0 & 33 & 24 & 72.7 \\
\hline 50 copies $/ \mu \mathrm{L}$ & 9 & 9 & 100.0 & 1 & 1 & 100.0 \\
\hline 75 copies $/ \mu \mathrm{L}$ & 9 & 9 & 100.0 & 1 & 1 & 100.0 \\
\hline 100 copies $/ \mu \mathrm{L}$ & 16 & 16 & 100.0 & 1 & 1 & 100.0 \\
\hline 250 copies $/ \mu \mathrm{L}$ & 7 & 7 & 100.0 & - & - & - \\
\hline
\end{tabular}

HSV: herpes simplex virus; VZV: varicella zoster virus; DNA: deoxyribonucleic acid; PCR: polymerase chain reaction. 


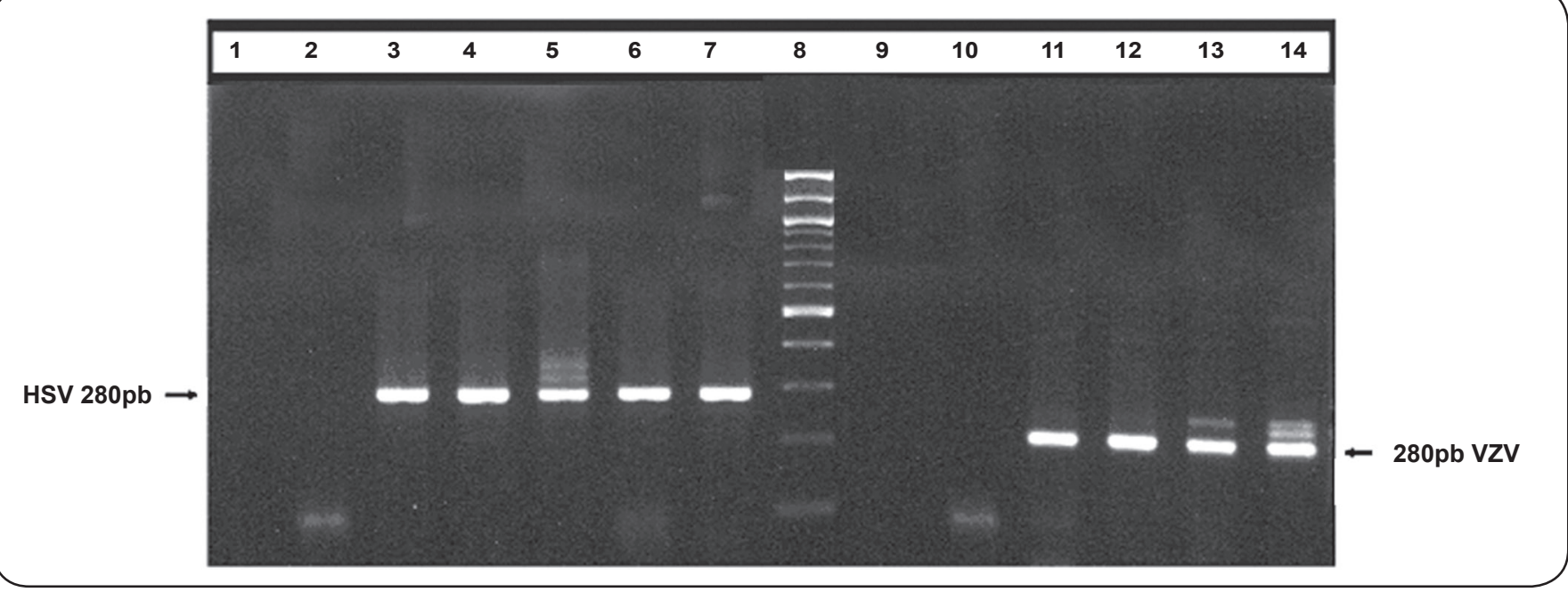

FIGURE 1 - Amplified viral nucleic acids from commercial control dilutions after agarose gel electrophoresis, ethidium bromide staining and UV transillumination. Lane 1: negative control. Lane 2: negative nucleic acid amplification (1 copy/ $\mu \mathrm{L}$ of HSV). Lanes 3 to 7: samples containing HSV DNA (dilutions of 5, 10, 50, 75 and 100 copies/ $\mu \mathrm{L}$, respectively). Lane 8: 100 to 1,000 bp MWM; Lanes 9 and 10: negative nucleic acid amplification (1 and 5 copies/ $\mu \mathrm{L}$ of VZV, respectively). Lanes 11 to 14: samples containing VZV DNA (dilutions 10, 50, 75 and 100 copies/ $\mu \mathrm{L}$, respectively). HSV: herpes simplex virus; VZV: varicella zoster virus; DNA: deoxyribonucleic acid; UV: ultraviolet; MWM: molecular weight marker.

VZV, we performed a single PCR assay using DNA extracted from HSV and VZV and from pathogens commonly isolated in CSF samples that may be involved in CNS infections, including Mycobacterium tuberculosis, cytomegalovirus, Epstein-Barr virus, human herpes virus 6, polyomavirus JC and BK, adenovirus, enterovirus and Toxoplasma gondii. The HSV and VZV primers used yielded specific fragments, confirming the specificity of the assay. HSV- (280bp) and VZV-specific bands (208bp) were compared with a molecular weight marker (MWM), as illustrated in Figure 1.

The application of molecular biology techniques has led to a revolution in the laboratory diagnosis of many infectious diseases of the CNS, as these techniques have high sensitivity and specificity. PCR has been extensively used in the diagnosis of CNS infections for its speed and capacity to detect small amounts of target DNA in the $\mathrm{CSF}^{7,8,11}$. Molecular analysis using PCR methods can be performed using commercial assays or in-house methods - in other words, lower-cost, laboratorystandardized alternatives ${ }^{12}$. Assays can be developed in-house by creating a multiplex panel containing multiple pairs of primers directed at various target genes, improving screening ${ }^{13}$. However, there is wide intra-laboratory variability in PCR assays, resulting from the use of different brands of reagents (enzymes and primers) and laboratory equipment (pipettes and cyclers) and inter-operator variability. The standardization of the technique is crucial, including the determination of the lower limit of detection.

In this study, we observed that the lower limit of detection for the proposed PCR assay was 5 copies/ $\mu \mathrm{L}$ for HSV and 10 copies/ $\mu \mathrm{L}$ for $\mathrm{VZV}$, indicating high analytical sensitivity. In a previous study comparing the detection limits of nested-PCR and realtime polymerase chain reaction (RT-PCR) for HSV, 100\% detection was reported for both methods for dilutions between 55 and 60 viral copies per reaction $(2.75-3 \text { copies } / \mu \mathrm{L})^{14}$. In addition, for reactions with dilutions between 2.5 and 12 copies, $50 \%$ were positive by RT-PCR, and $12.5 \%$ were positive by nested-PCR ${ }^{14}$. Furthermore, Tanaka et $\mathrm{al}^{15}$. developed a multiplex-PCR assay for rapid and simultaneous detection of six types of human herpes viruses, including HSV and VZV. In that study, the PCR assay had a lower detection limit of approximately 20 viral copies per reaction $(0.8$ copies $/ \mu \mathrm{L})$ for each type of virus ${ }^{15}$. In this regard, there is a small variation of sensitivity in different studies, which can be explained by several factors, such as the sequence of primers chosen, enzyme activity, DNA extraction method and the detection method used.

The introduction of molecular techniques, such as PCR, and the adoption of optimized protocols for the detection of infectious diseases are fundamental measures for the diagnosis of CNS infections. Comparing the results obtained in the literature with the results obtained in this study, it is possible to affirm that a lower limit of detection was detected for the proposed PCR assay for HSV and VZV, demonstrating that the protocol is highly sensitive. Determining the lower limits of detection of PCR assays and following quality assurance guidelines are key to ensuring the reliability of the results.

\section{CONFLICT OF INTEREST}

The authors declare that there is no conflict of interest.

\section{FINANCIAL SUPPORT}

We thank the Research Incentive Fund (Fundo de Incentivo à Pesquisa e Eventos - FIPE), the Graduate Research Group (GPPG) and Hospital de Clínicas de Porto Alegre. 


\section{REFERENCES}

1. Benedetti J, Corey L, Ashley R. Recurrence rates in genital herpes after symptomatic first episode infection. Ann Intern Med 1994; 121:847.

2. Weidmann M, Armbruster K, Hufert FT. Challenges in designing a Taqmanbased multiplex assay for the simultaneous detection of Herpes simplex virus types 1 and 2 and varicella-zoster virus. J Clin Virol 2008; 42:326-334.

3. DeBiasi RL, Kleinschmidt-DeMasters BK, Weinberg A, Tyler KL. Use of PCR for the diagnosis of herpes virus infections of the central nervous system. J Clin Virol 2002; 25:5-11.

4. Ihekwaba UK, Kudesia G, McKendrick MW. Clinical features of viral meningitis in adults: significant differences in cerebrospinal fluid findings among herpes simplex virus, varicella zoster virus, and enterovirus infections. Clin Infect Dis 2008; 47:783-789.

5. Gilden D. Varicella zoster virus and central nervous system syndromes. Herpes 2004; 11 (supl II):89A-94A.

6. Pahud BA, Glaser CA, Dekker CL, Arvin AM, Schmid DS. Varicella zoster disease of the central nervous system: epidemiological, clinical, and laboratory features 10 years after the introduction of the varicella vaccine. J Infect Dis 2011; 203:316-323.

7. Davies NW, Brown LJ, Gonde J, Irish D, Robinson RO, Swan AV, et al. Factors influencing PCR detection of viruses in cerebrospinal fluid of patients with suspected CNS infections. J Neurol Neurosurg Psychiatry 2005; 76:82-87.
8. Salamano R, Scavone C, Baz M, Rey A, Gonzáles G, Perna A, et al. Meningitis y encefalitis víricas em Uruguay. Rev Med Urug 2009; 25:212-218.

9. Read SJ, Kurtz JB. Laboratory diagnosis of common viral infections of the central nervous system by using a single multiplex PCR screening assay. J Clin Microbiol 1999; 37:1352-1355.

10. Abramson JH. WINPEPI (PEPI-for-Windows): computer programs for epidemiologists. Epidemiol Perspectives Innovations 2004; 1:6.

11. Kawada JI, Kimura H, Ito Y, Hoshino Y, Kitajima NT, Ando Y, et al. Comparison of Real-Time and Nested PCR assays for detection of herpes simplex virus DNA. Microbiol Immunol 2004; 48:411-415.

12. Sperhacke RD, Mello FC, Zaha A, Kritski A, Rossetti ML. Detection of Mycobacterium tuberculosis by a polymerase chain reaction colorimetric dot-blot assay. Int J Tuberc Lung Dis 2004; 8:312-317.

13. Mielle-Filho A, Remualdo V. Biologia molecular aplicada ao diagnóstico de doenças infecciosas. Prática hospitalar 2007; 53:33-35.

14. Röhl EF, Lindell AT, Grillner L, Aurelius E. Increased detection rate in diagnosis of herpes simplex virus type 2 meningitis by real-time PCR using cerebrospinal fluid samples. J Clin Microbiol 2007; 45:2516-2520.

15. Tanaka T, Kagawa K, Sasa H, Moroyama S, Furuya K, Sato K. Rapid and simultaneous detection of 6 types of human herpes virus (herpes simplex virus, varicella-zoster virus, epstein-barr virus, cytomegalovirus, human herpes virus $6 \mathrm{~A} / \mathrm{B}$, and human herpes virus 7) by multiplex PCR assay. Biomedical Research 2009; 30:279-285. 